\title{
Xenophagus, a new genus of pleasing fungus beetles (Coleoptera: Erotylidae) from Baltic Amber
}

\author{
Хеnophagus, новый род жууков-грибовиков \\ (Coleoptera: Erotylidae) из балтийского янтаря
}

\author{
G.Yu. Lyubarsky ${ }^{1}$, E.E. Perkovsky ${ }^{2}$ \\ Г.Ю. Аюбарский, Е.Э. Перковский
}

\footnotetext{
1 Zoological Museum, Moscow Lomonosov State University, Bol'shya Nikitskaya 2, Moscow 125009, Russia. E-mail: lgeorgy@rambler.ru Зоологический музей, Московский государственный университет им. М.В. Ломоносова, Большая Никитская ул., 2, Москва 125009, Россия.

${ }^{2}$ Schmalhausen Institute of Zoology, National Academy of Sciences of Ukraine, Bogdan Khmielnitsky str. 15, Kiev 01601, Ukraine. E-mail: perkovsk@gmail.com
}

KEY WORDS: Erotylidae, Xenoscelinae, Xenophagus, taxonomy, Late Eocene, Baltic amber.

КЛЮЧЕВЫЕ СЛОВА: Erotylidae, Xenoscelinae, Xenophagus, таксономия, поздний эоцен, балтийский янтарь.

ABSTRACT. Based on a fossil specimen from the Late Eocene Baltic amber (Kaliningrad region, Yantarnyi) Xenophagus popovi gen.n., sp.n., is described. The new genus is similar to the extant genus Xenoscelis Wollaston 1864, and monotypic genus Xenohimatium Lyubarsky et Perkovsky, 2012 from the Late Eocene Rovno amber (Ukraine), differing in presence of submetacoxal lines, and elytral punctation confused.

РЕЗЮМЕ. Из позднеэоценового балтийского янтаря (Калининградская область, Янтарный) описан Xenophagus popovi gen.n., sp.n. Новый род наиболее близок к современному роду Xenoscelis Wollaston 1864 и монотипическому роду Xenohimatium Lyubarsky et Perkovsky, 2012 из позднеэоценового ровенского янтаря (Украина), отличается от них наличием субметакоксальных линий, спутанной пунктировкой надкрылий.

\section{Introduction}

The family Erotylidae is a group of small and medium size beetles with about 3500 described species in almost 300 genera, represented in all continents except Antarctica [Wegrzynowicz, 2002, 2007; Leschen, 2003; Leschen et al., 2010]. The family belong with the superfamily Cucujoidea. The phylogenetic position of the Erotylidae is described in Robertson et al. [2004, 2015]. The classification of the family was most recently revised by Leschen [Leschen, Wegrzynowicz, 1998; Leschen, 2003]. The family Erotylidae includes six subfamilies (Xenoscelinae, Pharaxonothinae, Loberinae, Languriinae, Cryptophilinae, and Erotylinae).

Erotylidae are predominantly mycophagous, some genera are phytophagous or saprophagous, and some species have been found feeding on the pollen of cycads [Windsor et al., 1999; Leschen, Buckley, 2007]. Some species are found in the nests of social insects.

\section{Palaeontological data}

Palaeontological data concerning the family Erotylidae were reported by Wegrzynowicz [2002]. A few species of the genera Tritoma Herbst, 1793 and Dacne Latreille, 1797 have been described or recorded from Dominican amber [Skelley, 2003], as well as some genera were recorded from Late Eocene Baltic amber (Cryptophilus Reitter, 1874, Dacne, Tritoma) and copal (Erotylus Fabricius, 1775) [Poinar, 1992; Skelley, 1997; Spahr, 1981a, b]. Later new species of Triplax Herbst, 1793 was described from Late Eocene Bitterfeld amber [Alexeev, 2014]. Several genera have been recently described in the subfamily Xenoscelinae. The genus Xenohimatium was described from Late Eocene Rovno amber (Ukraine) [Lyubarsky, Perkovsky, 2012]. The genus Warnis Lyubarsky et al., 2016 was described from Baltic amber [Lyubarsky et al., 2016]. Paleontological data concerning the subfamilies Pharaxonothinae, Loberinae, and Languriinae are not available. A pair of elytra of an erotylid were found in shales of an Eocene lake at Quilchena, British Columbia [Archibald, Mathewes, 2000]. Another erotylid was recorded in Barremian Lebanese amber [Kirejtshuk, Azar, 2013]; both Quilchena and Lebanese specimens are still undescribed.

The new Baltic amber pleasing fungus genus was found in collection of Christel and Hans Werner Hoffeins $(\mathrm{CCHH})$.

Photographs were taken at the Schmalhausen Institute of Zoology (Kiev, SIZK) using the microscope Leica MZ 16. 


\section{Taxonomy}

\section{Order Coleoptera}

Superfamily Cucujoidea Latreille, 1802

Family Erotylidae Latreille, 1802

Subfamily Xenoscelinae Ganglbauer, 1899

Xenophagus Lyubarsky et Perkovsky, gen.n.

Type species: Xenophagus popovi Lyubarsky et Perkovsky, sp.n.

DIAGNOSIS. Pronotal pits absent, pronotum parallelsided, submetacoxal lines present, length of tarsomere 1 a little greater than that of tarsomere 2 .
DESCRIPTION. Body very elongated, narrow, glabrous. Antenna with 11 antennomeres and a 3-segmented club. Frontoclypeal suture absent. Antennal insertion hidden in dorsal view. Supraocular line present. Anterior angles of pronotum poorly developed (Figs 1-2). Lateral margin of pronotum not serrate, smooth. Procoxal cavity closed. Width of mesoventral process narrower than mesocoxa. Longitudinal line of metasternum present. Mesocoxae separated by ca. 0.5 1.0 times of coxal width. Submetacoxal lines present (Fig. 7). Foretibia and mesotibia with 2 short spurs in apex. Tarsi 5-5-5. Tarsomeres $2^{\text {nd }}$ and $3^{\text {rd }}$ not lobed. Tarsomere 4 not reduced. Elytral puncturation confused. Epipleuron complete to apex of elytron.
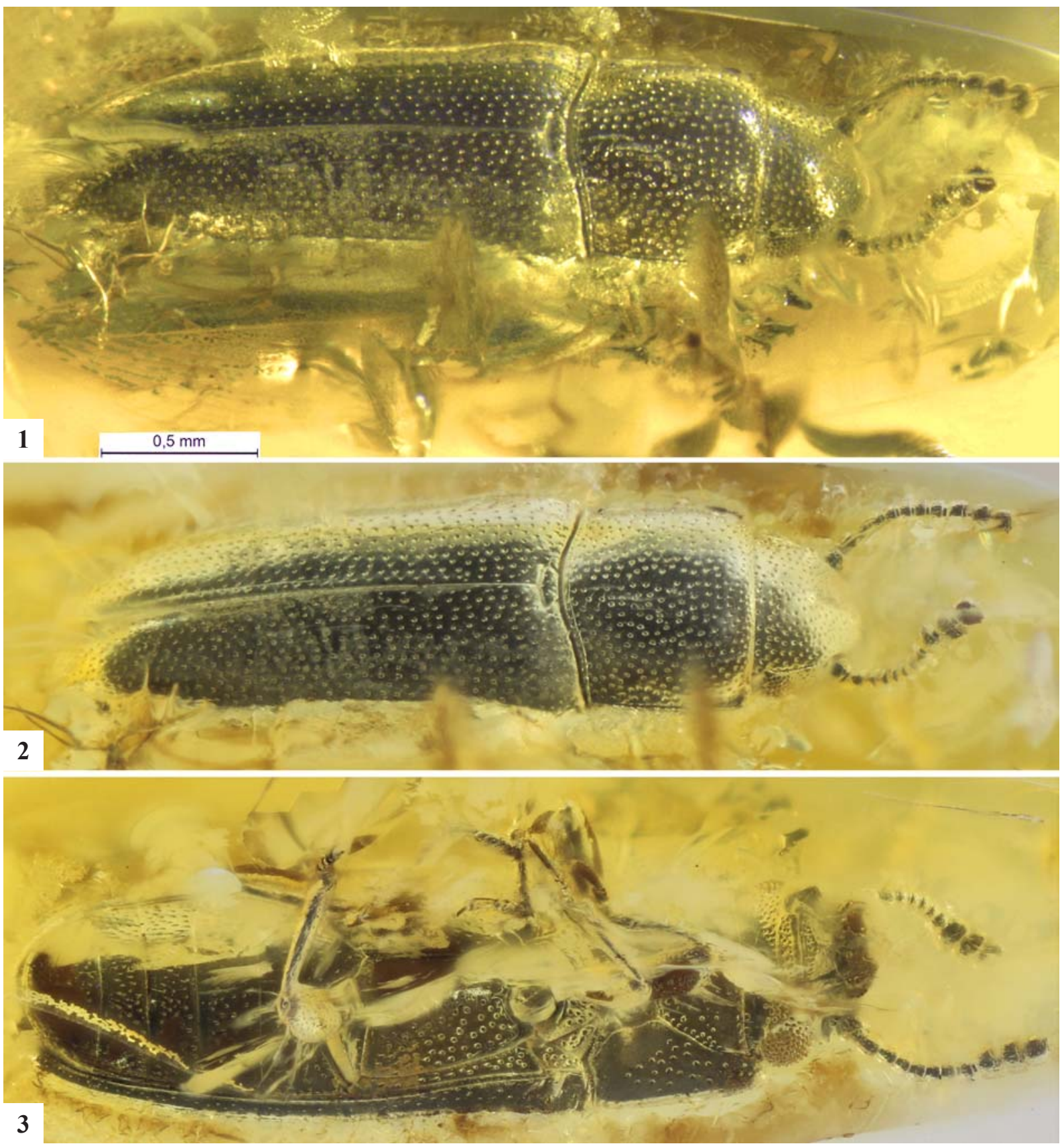

Figs 1-3. Holotype Xenophagus popovi sp.n., photo: 1 - dorsal view; 2 - dorsal view, with clearly visible changes in the front angles of pronotum; 3 - ventral view.

Рис. 1-3. Голотип Xenophagus popovi sp.n., фотография: 1 - сверху; 2 - сверху, заметны утолщения передних углов переднеспинки; 3 - снизу. 

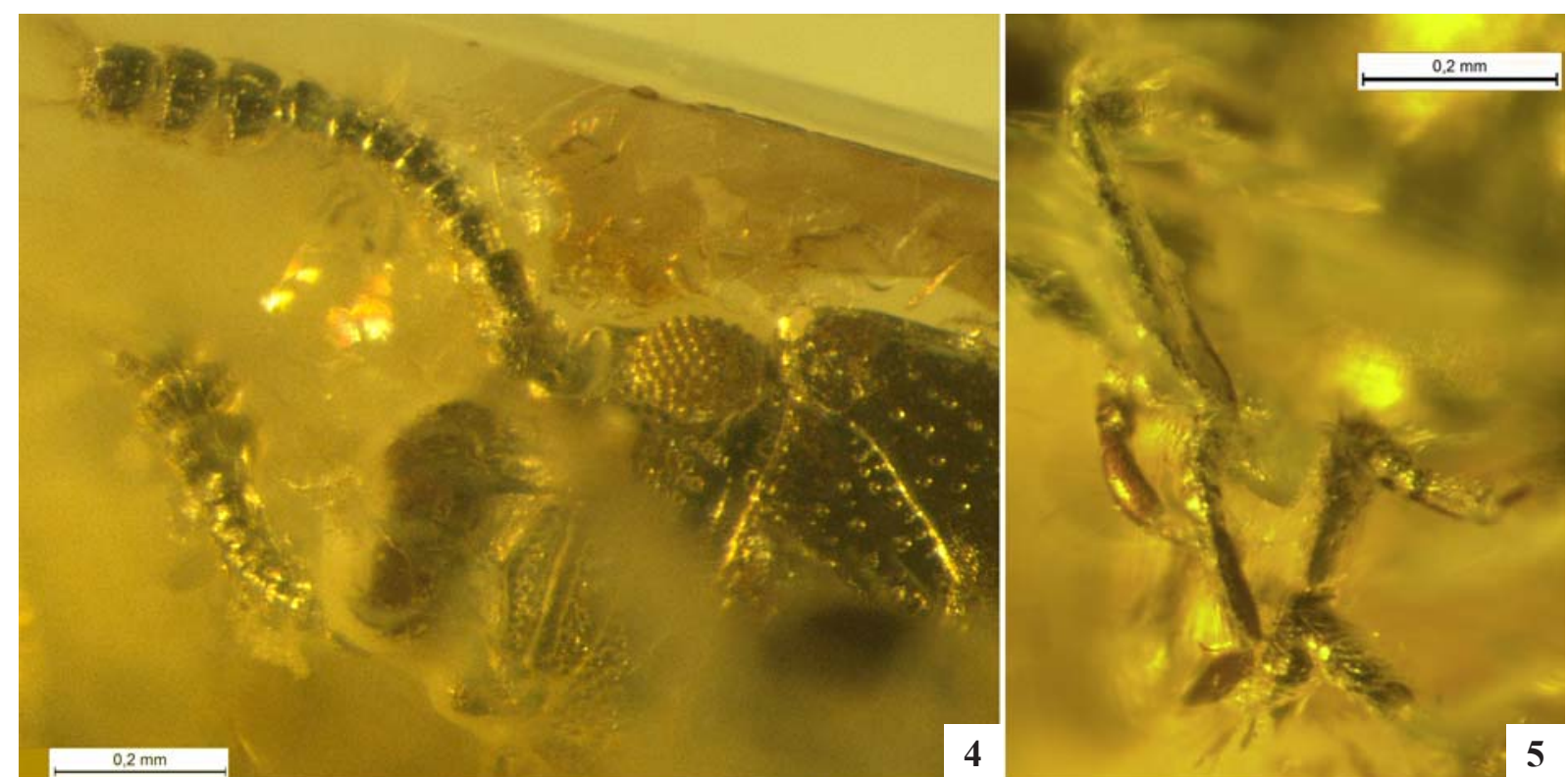

Figs 4-6. Holotype Xenophagus popovi sp.n., photo: 4-bottom view of the head; 5-6-front and middle legs from two perspectives.

Рис. 4-6. Голотип Xenophagus popovi sp.n., фотография: 4 голова снизу; 5-6 - передние и средние ноги в двух ракурсах.

ETYMOLOGY. The genus name is grammatically masculine. It is compounded from parts of the names of two genera, Xenoscelis Wollaston, 1864 and Chinophagus Lyubarsky, 1997.

\section{Xenophagus popovi Lyubarsky et Perkovsky, sp.n.} Figs 1-7.

MATERIAL. Holotype: CCHH 26-1, Yantarnyi, Baltic amber, Late Eocene. Material and types will be deposited at the amber collection of Senckenberg Deutsches Entomologisches Institut Müncheberg (SDEI), Germany. Collection code: CCHH.

DESCRIPTION. Body parallel-sided, without hairs, 2.5 times longer than wide (Fig. 1), dorsum weakly convex. Body length $2.5 \mathrm{~mm}$, width $1.0 \mathrm{~mm}$.

Head width including eyes 0.8 of the pronotal width. Shape of eye hemispherical, eyes relatively large. Length of eye equal to half length of head. Facet medium size, approximately equal to diameter of puncture. Punctuation of head: punctures medium size, distance between neighbouring punctures equal to or a bit greater than one diameter of puncture. Frons weakly convex, punctuate. Antennae with 11 segments and a 3-segment club, relatively short, not reaching beyond hind edge of pronotum. Antennal club slightly flattened. Club with 3 loosely connected segments, $9^{\text {th }}$ and $10^{\text {th }}$ antennomeres conical, $10^{\text {th }}$ slightly transverse (Figs 1-2). $1^{\text {st }}$ antennomere broad, rounded. $2^{\text {nd }}$ antennomere longest of the segments of flagellum, and other segments of flagellum elongate, at least 1.5 times longer than wide. Terminal antennomere piriform, 1.3 times longer than wide, with pointed narrow tip. Antennal furrows absent.

Pronotum parallel-sided, without callosity and teeth, anterior angles very slightly thickened, length of pronotum equal to width, equal to 0.4 length of elytra. Lateral margin on the front corners of the pronotum slightly flattened. Anterior margin straight. Lateral margins and base of pronotum with border. Base of pronotum with shallow transverse depression; basal pits absent, basal furrow absent. Posterior margin with basal lobe. Pronotum strongly and densely punctated, distance

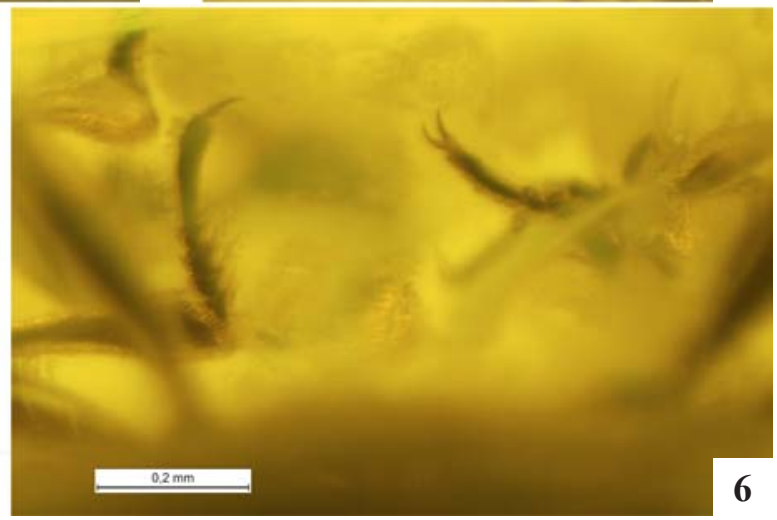

between neighbouring punctures about 1.5 diameter of puncture. Posterior angles rectangular.

Prosternum in front of procoxae short. Distance between metacoxae greater than diameter of metacoxa. Pre-, meso-, and metasternum strongly and densely punctated. Legs slender, tibia slightly dilated apically. Tibia with crown of bristles in apex. Tarsomeres elongated, without lobes (Figs 3-4). Tarsomeres 1-4 about equal in length, the longest being tarsomere 5, which is almost equal in length to all the other taken together. Claw without notches, smooth, about $1 / 3$ of the length of the $5^{\text {th }}$ tarsomere.

Scutellum transverse, 2 times longer than wide. Elytral length 2.2 times greater than width. Elytra narrowed and rounded apically. Elytra strongly punctated, distance between neighbouring punctures about 2 diameters of puncture. Elytral surface slightly shagreened.

Number of ventrites: 5. Abdominal ventrite 1 only slightly longer than ventrite 2 (Fig. 7). Abdominal punctures with bristles.

REMARKS. Subfamily Xenoscelinae included the following genera: extant Loberonotha Sen Gupta et Crowson, 1969 (1 species; New Zealand), Macrophagus Motschulsky, 1845 (1 species; Asia and Europe), Othniocryptus Sharp, 1900 (1 species; Neotropical), Protoloberus Leschen, 2003 (1 species; Australia), Xenocryptus Arrow, 1929 (2 species; Africa and Australia), Xenoscelis Wollaston, 1864 (1 species; Mediterranean), Zavaljus Reitter, 1880 


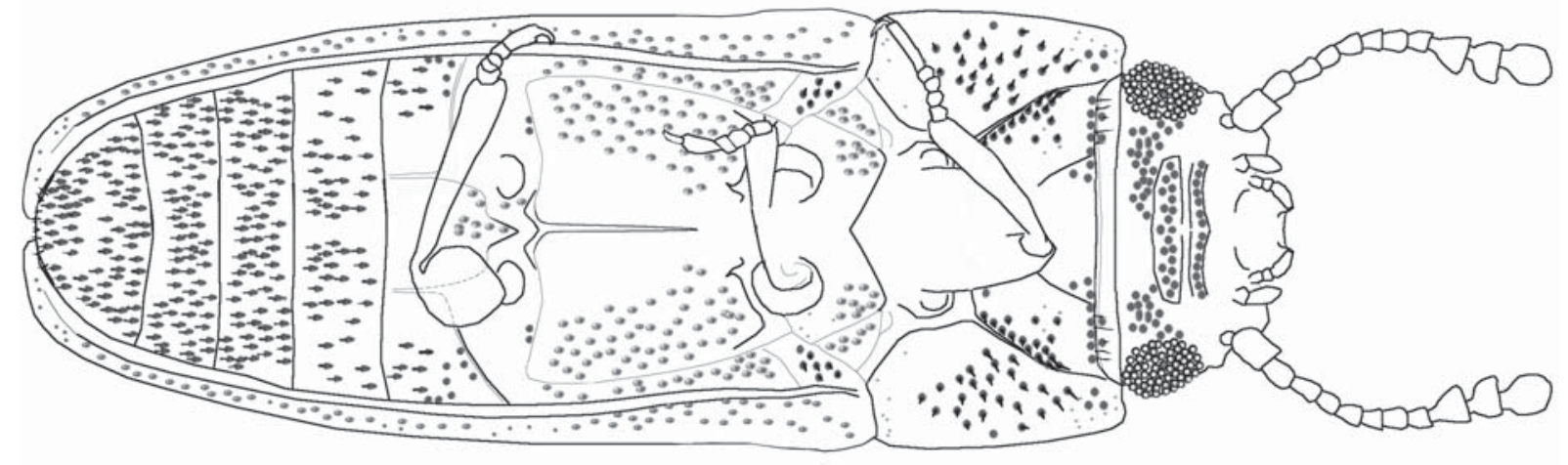

Fig. 7. Holotype Xenophagus popovi sp.n., ventral view, drawing.

Рис. 7. Голотип Xenophagus popovi sp.n., снизу, реконструкция.

(1 species; Northern Europe), Arrowcryptus Leschen et Wegrzynowicz (Africa) and extinct monotypic genera Xenohimatium Lyubarsky, Perkovsky, 2012 from the Late Eocene Rovno amber (Ukraine) and Warnis Lyubarsky et al., 2016 from Late Eocene Baltic amber.

From all taxa of the subfamily the new genus differs by combination of three characters: body glabrous, submetacoxal lines present, and elytral punctation confused.

The character "submetacoxal lines" in many genera of the Erotylidae is polymorphic: lines are present or absent among the species of the genera Tritoma, Crotchia Fowler, 1886, Crowsonguptus Leschen et Wegrzynowicz, 1998, Fitoa Dajoz, 1973, Loberopsyllus Martinez et Barrera, 1966, Loberoschema Reitter, 1896, Loberus LeConte, 1861, Platoberus Sharp, 1900, Stengita Reitter in Harold, 1875, Toramus Grouvelle, 1916 [Leschen, 2003]. Apparently, the importance and stability of this character in the group is not very high.

ETYMOLOGY. The species is named in honour of the famous paleoentomologist Yuri Popov.

ACKNOWLEDGMENTS. We are grateful to Christel and Hans Werner Hoffeins (Hamburg, Germany) for providing the material, Vitaly Nazarenko (SIZK) - for help with photos. The work of the first author has been supported by the grant AAAA-A16-116021660077-3.

\section{References}

Alekseev V.I. 2014. A new species of Triplax Herbst, 1793 (Coleoptera: Erotylidae) from Bitterfeld amber // Baltic Journal of Coleopterology. Vol.14. P.171-177.

Archibald S.B., Mathewes R.W. 2000. Early Eocene insects from Quilchena, British Columbia, and their paleoclimatic implications // Canadian Journal of Zoology. Vol.78. P.1441-1462.

Kirejtshuk A.G., Azar D. 2013. Current knowledge of Coleoptera (Insecta) from the Lower Cretaceous Lebanese amber and taxonomical notes for some Mesozoic groups // Terrestrial Arthropod Reviews. Vol.6. P.103-134.

Leschen R.A.B. 2003. Erotylidae (Insecta: Coleoptera: Cucujoidea) Phylogeny and review // Fauna of New Zealand. Vol.47. P.1-108.

Leschen R.A.B., Buckley T.R. 2007: Multistate Characters and Diet Shifts: Evolution of Erotylidae (Coleoptera) // Systematic biology. Vol.56. P.97-112.

Leschen R.A.B., Skelley P.E., McHugh J.V. 2010. 10.7. Erotylidae Leach, 1815. In: Leschen, R.A.B., Beutel, R.G., Lawrence, J.F. (eds.). Coleoptera, beetles. Vol.2: Morphology and systematics
(Elateroidea, Bostrichiformia, Cucujiformia partim) // Kristensen N.P., Beutel R.G. (eds.). Handbook of zoology. A natural history of the phyla of the animal kingdom. Vol. IV. Arthropoda: Insecta. Part 38. Walter de Gruyter: Berlin, New York. P.311319.

Leschen R.A.B., Wegrzynowicz P. 1998. Generic Catalogue and Taxonomic Status of Languriidae (Cucujoidea) // Annales Zoologici (Warszawa). Vol.48. Nos3-4. P.221-243.

Lyubarsky G.Yu., Perkovsky E.E. 2012. A new genus Erotylidae from Eocene amber (Coleoptera: Clavicornia) // Russian Entomological Journal. Vol.21. No.1. P.35-38.

Lyubarsky G.Yu., Perkovsky E.E., Alekseev V.I. 2016. The Firs Record of the Subfamily Xenoscelinae (Coleoptera, Erotylidae) from the Baltic Amber // Paleontological Journal. Vol.50. No.9. P.963-969.

Poinar G.O. 1992. Life in Amber. Stanford: Stanford University Press. XIII +350 pp.

Robertson J.A., McHugh J.V., Whiting M.F. 2004. A molecular phylogenetic analysis of the pleasing fungus beetles (Coleoptera: Erotylidae): evolution of colour patterns, gregariousness and mycophagy // Systematic Entomology. Vol.29. P.173-187.

Robertson J.A., Slipinski A., Moulton M., Shockley F.W., Giorgi A., Lord N.P., McKenna D.D., Tomaszewska W., Forrester J., Miller K.B., Whiting M.F., McHugh J.V. 2015. Phylogeny and classification of Cucujoidea and the recognition of a new superfamily Coccinelloidea (Coleoptera: Cucujiformia) // Systematic Entomology. Vol.40. P.745-778.

Skelley P.E. 1997. A new species of Dacne Latreille from Dominican amber, with a key and checklist to known species of Dacne (Erotylidae: Dacninae) // Annales Zoologici. Vol.47. Nos1/2. P.49-53.

Skelley P.E. 2003. The genus Dacne Latreille (Coleoptera: Erotylidae) in tropical America // Insecta Mundi. Vol.17. Nos1-2. P.111-117.

Spahr U. 1981a. Bibliographie der Berstein- und Kopal-Käfer (Coleoptera) // Stuttgarter Beiträge zur Naturkunde, Serie B (Geologie und Paläontologie). Bd.72. S.1-21.

Spahr U. 1981b. Systematischer Katalog der Berstein- und KopalKäfer (Coleoptera) // Stuttgarter Beiträge zur Naturkunde, Serie B (Geologie und Paläontologie). Bd.80. S.1-107.

Wegrzynowicz P. 2002. Morphology, phylogeny and classification of the family Erotylidae based on adult characters (Coleoptera: Cucujoidea) // Genus. Vol.13. No.4. P.435-504.

Wegrzynowicz P. 2007. Erotylidae // Löbl I., Smetana A. (eds.). Catalogue of Palaearctic Coleoptera, vol. 4. Apollo Books. Stenstrup. P.531-546

Windsor D., Ness J., Gomez L. D., Jolivet P. 1999. Species of Aulacoscelis Duponchel and Chevrolat (Chrysomelidae) and Nomotes Gorham (Languriidae) feed on fronds of Central American Cycads // Coleopterists Bulletin. Vol.53. No.3. P.217-231. 